\title{
Combretastatin A-4: The Antitubulin Agent that Inspired the Design and Synthesis of Styrene and Spiroisatin Hybrids as Promising Cytotoxic, Antifungal and Antiviral Compounds
}

\author{
Yaneth M. Brand, ${ }^{\circledR *, a}$ Vladimir V. Kouznetsov, ${ }^{\circledR b}$ Carlos E. Puerto, ${ }^{\circledR b, c}$ \\ Vicky C. R. Linares, ${ }^{\oplus a}$ Verónica T. Castaño ${ }^{a}$ and Liliana Betancur-Galvis ${ }^{a}$ \\ ${ }^{a}$ Group of Investigative Dermatology, Institute of Medicinal Research, Medicine Faculty, \\ University of Antioquia, 1226, 050022 Medellin, Colombia \\ ${ }^{b}$ Laboratorio de Química Orgánica y Biomolecular, Centro de Materiales y Nanociencias (CMN), \\ Parque Tecnológico Guatiguará, Universidad Industrial de Santander, km 2 vía Refugio, \\ A.A. 681011 Piedecuesta, Colombia \\ 'Laboratorio de Química Orgánica Aplicada, Universidad Manuela Beltrán, \\ Cl. 33 No. 26-34, A.A. 680002 Bucaramanga, Colombia
}

\begin{abstract}
The design of a series of styrene and spiroisatin hybrids was based on the structure of combretastatin A-4 1. This library of 20 compounds were synthesized with the pharmacophoric units: 3,4,5-trimethoxy or/and 4-hydroxy-3-methoxy phenyl moities in their structure. Thereby, the libraries of $\beta$-nitrostyrenes 10a-10c, spiroisatin-dihydroquinolines 14a-14c, spiroisatinthiazolidinones 17a-17c and spiroisatin-nitropyrrolizidines $20 \mathbf{a}-\mathbf{2 0 k}$ were evaluated for their in vitro cytotoxic, anti-proliferative, antifungal and antiviral activities. Biological results revealed that among these compounds, $\beta$-nitrostyrenes 10a-10c exhibited significant cytotoxicity (HeLa and Jurkat tumor cells) and antifungal (T. mentagrophytes) activities. Moreover, the spiroisatindihydroquinoline 14a and 14c showed promising cytotoxicity (U937 cells). 14a-14c molecules were active against human herpesviruses serotypes 1 and 2 (HHV-1 and HHV-2), but only 14a and 14b were effective against dengue virus serotype 2 (DENV-2). The spiroisatin-nitropyrrolizidine 20c exhibited moderate anti-herpetic activity, while $17 \mathbf{c}$ spiroisatin-thiazolidinone derivative also reduced the infection of HHV-1 and DENV-2. Finally, the molecular docking showed that these kind of molecules interact with the subunit $\alpha / \beta$-tubulin.
\end{abstract}

Keywords: combretastatin A-4, $\beta$-nitrostyrenes, spiroisatin hybrids, anti-proliferative, antifungal and antiviral activities

\section{Introduction}

Combretastatin A-4 1 (CA-4), the most potent and studied compound isolated from the bark of the South African willow tree Combretum caffrum, ${ }^{1}$ stands out among other members of the combretastatin family due to its cytotoxic properties as inhibitor of angiogenesis and tubulin polymerization. ${ }^{2}$

The constant assembly (polymerization) and disassembly (depolymerization) of microtubules, formed by a heterodimer constituted by $\alpha$ - and $\beta$-tubulin subunits, ${ }^{3}$ plays a crucial role in mitosis and cell division where they are involved during the spindle formation, migration,

*e-mail: yaneth.miranda@udea.edu.co cell shape organization, chromosomal separation and transportation of vesicles and mitochondria. ${ }^{4}$ With a rather simple structure, CA-4 has shown to inhibit the polymerization of tubulin by binding to the colchicine site and thus, disrupting the tubulin-microtubule dynamics leading to mitotic arrest and eventually the cell death by apoptosis. ${ }^{5}$ Nevertheless, the major drawbacks of CA-4 are its poor aqueous solubility, low bioavailability, cumulative toxicities and short biological half-life that have promoted its derivatization during the last decades. ${ }^{6}$

Several structure-activity relationship studies of CA-4 has revealed that the cis configuration of the double bond, the 3,4,5-trimethoxy groups on the A-ring, and the meta-hydroxy and para-methoxy groups on the B-ring are fundamental for its main biological activity. ${ }^{7}$ Thereby, 
CA-4 has inspired the synthesis and biological evaluation of different cytotoxic analogues containing these privileged pharmacophores: the disodium phosphate prodrug CA-4P 2, ${ }^{8}$ colchicine $3,{ }^{9}$ podophyllotoxin $4,{ }^{10}$ eugenol $5^{11}$ and some oxindole derivatives 6-7 $\mathbf{7}^{12}$ (Figure 1).

Besides the cytotoxic activity against a range of human cancer cell lines, in which CA-4 1 induces the destabilization of proteins associated with the cytoskeleton, this compound is responsible for altering the coordination of many cellular processes, including the cell cycle, movement, adhesion, morphogenesis and contraction. ${ }^{13}$ Several reports have determined that these cellular processes are involved in different infection processes of some pathogens such as bacteria, ${ }^{14}$ parasites,,${ }^{15}$ fungi ${ }^{16}$ and viruses. ${ }^{17}$

In particular, CA-4 and some analogues have exhibited antifungal and antiviral activities whose mechanism of action involves the inhibition of tubulin polymerization or arrest of the cell cycle at different stages. For example, synthetic combretastatin analogues have exhibited relevant activity against Trichophyton rubrum, Trichophyton mentagrophytes, Aspergillus fumigatus and Saccharomyces cerevisiae through the regulation of signaling pathways. ${ }^{18}$

On the other hand, the use of microtubule inhibitors before the viral infection and during various phases of the virus life cycle, delays the intracellular transport of virions leading to the accumulation of viral particles at intracellular level. ${ }^{19,20}$ In fact, ribonucleic acid (RNA) and deoxyribonucleic acid (DNA) viruses regulate microtubule during the different stages of the replicative cycle. For example, microtubule-associated proteins such as dynein, kinesin as well as dynactin 1 direct the transport of human herpesviruses serotype 1 (HHV-1), a DNA virus, inside the cell (dynactin subunit 1 (DCTN1)). ${ }^{21}$ In the case of RNA viruses, it has been described the role of microtubules in early stages of infection of human immunodeficiency virus (HIV). Additionally, the flaviviruses use these structures to promote a reconfiguration of the cytoplasmic compartments that are important for the genome replication and translation of viral protein. ${ }^{22}$

Considering both the previously described data ${ }^{23}$ regarding viral modulation of microtubules and the current need to research on synthesis and biological evaluation of small molecules inspired on the structure of CA-4 1, our screening program for new bioactive heterocycles ${ }^{23}$ has focused this research on: (i) design and synthesis of a 20 -member library of styrene and spiroisatin hybrids containing the 3,4,5-trimethoxyphenyl and/or the 4-hydroxy-3-methoxyphenyl as pharmacophoric subunits; (ii) evaluation of the cytotoxic activity in tumor cell lines (HeLa (cervix epitheloid adenocarcinoma cell), Jurkat (acute T cell leukemia), U937 (promonocytic cell) and Vero (African green monkey kidney, Cercopithecus aethiops)); (iii) study of the antifungal activities in pathogen dermatophytes (T. mentagrophytes, T. rubrum and F. oxysporum); (iv) determination of the antiviral activity in human herpesvirus 1 and 2 (HHV-1 and HHV-2), and dengue virus serotype 2 (DENV-2) of these molecules and some related tubulin inhibitors, and $(v)$ the study of the possible interactions of these molecules with the active site of the tubulin target through molecular docking studies.

\section{Results and Discussion}

The preparation of the first library, the $\beta$-nitrostyrenes 10a-10c, is shown in Scheme 1. The corresponding benzaldehydes $8 \mathbf{8 a}-\mathbf{8} \mathbf{c}$ reacted with nitromethane 9 through a Knoevenagel condensation catalyzed by a ethanolamine supported on silica gel $\left(\mathrm{ETAM} / \mathrm{SiO}_{2}\right)$ at $90{ }^{\circ} \mathrm{C}$ to furnish the styrene derivatives. ${ }^{24}$

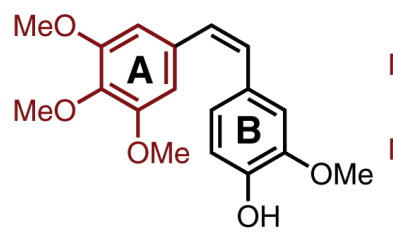

$1 \mathrm{CA}-4, \mathrm{R}=\mathrm{H}$

$2 \mathrm{CA}-4 \mathrm{P}, \mathrm{R}=\mathrm{OPO}_{3} \mathrm{Na}_{2}$

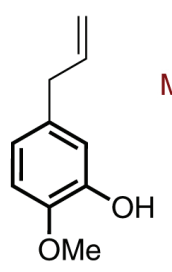

5<smiles>COc1cc2c(c(OC)c1OC)-c1ccc(OC)c(=O)cc1[C@@H](NC(C)=O)CC2</smiles><smiles>COc1cc([C@H]2c3cc4c(cc3[C@@H](O)[C@@H]3COC(=O)[C@@H]23)OCO4)cc(OC)c1OC</smiles>

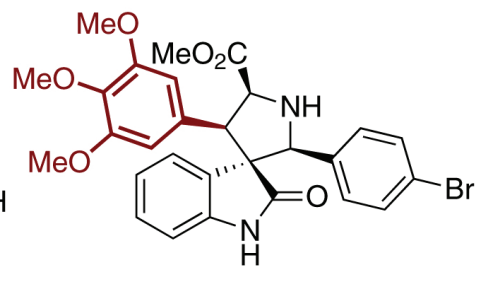

6<smiles>COc1cc(/C=c2\s/c(=C3/C(=O)Nc4ccc(F)cc43)n(CCN(C)C)c2=O)cc(OC)c1OC</smiles>

Figure 1. CA-4 (1) and some synthetic and natural derivatives (2-7) containing the pharmacophoric moieties related with its cytotoxic activity. 
<smiles>[R]c1cc(C=O)cc([R3])c1[R]</smiles><smiles>O=[N+]([O-])C=Cc1ccc2c(c1)OCO2</smiles>

$10 a$<smiles>COc1ccc(/C=C/[N+](=O)[O-])cc1OC</smiles>

10b<smiles>COc1cc(/C=C/[N+](=O)[O-])cc(OC)c1OC</smiles>

Scheme 1. Synthesis of $\beta$-nitrostyrenes 10a-10c through a Knoevenagel condensation catalyzed by ethanolamine supported on silica gel $\left(\mathrm{ETAM}_{\mathrm{SiO}}\right)$.

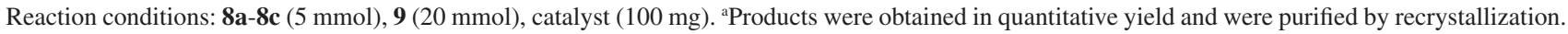

The next group of molecules, the spiroisatindihydroquinoline hybrids 14a-14c containing the 4-hydroxy-3-methoxyphenyl moiety, were synthesized through a two-step protocol in which the respective anilines 12a-12c were condensated with isatin $\mathbf{1 1}$ to give the corresponding ketimine-isatin products. These intermediates were reacted in a second step with transisoeugenol 13 via Povarov reaction catalyzed by $\mathrm{BF}_{3} \cdot \mathrm{OEt}_{2}$, given the desired adducts $14 \mathbf{a}-14 \mathbf{c}$ in moderate yields (Scheme 2). ${ }^{25}$

Next, the spiroisatin-thiazolidinone hybrids $\mathbf{1 7 a - 1 7 c}$ containing the 3,4,5-trimethoxyphenyl moiety were prepared in another two-step synthetic methodology in which the first multicomponent reaction between isatin 11, anilines 12d-12f and thioglycolic acid $\mathbf{1 5}$ afforded the respective 2,3-disubstituted-4-thiazolidinones as intermediates (Scheme 3). Then, the latter compounds underwent a Knoevenagel condensation catalyzed by $t$-BuOK at $90{ }^{\circ} \mathrm{C}$ with 3,4,5-trimethoxybenzaldehyde $\mathbf{1 6}$, leading to the desired compounds $\mathbf{1 7 a - 1 7} \mathbf{c}$ in good yields (Scheme 3).

Finally, the spiroisatin-nitropyrrolizidine hybrids 20a-20k were synthesized through a multicomponent and regioselective 1,3-dipolar cycloaddition between isatin derivatives 18a-18c, L-proline 19 and the $\beta$-nitrostyrenes 10a-10c under aqueous media to furnish the title compounds 20a-20k with the 3,4,5-trimethoxyphenyl moiety in excellent yields (Scheme 4). ${ }^{26}$

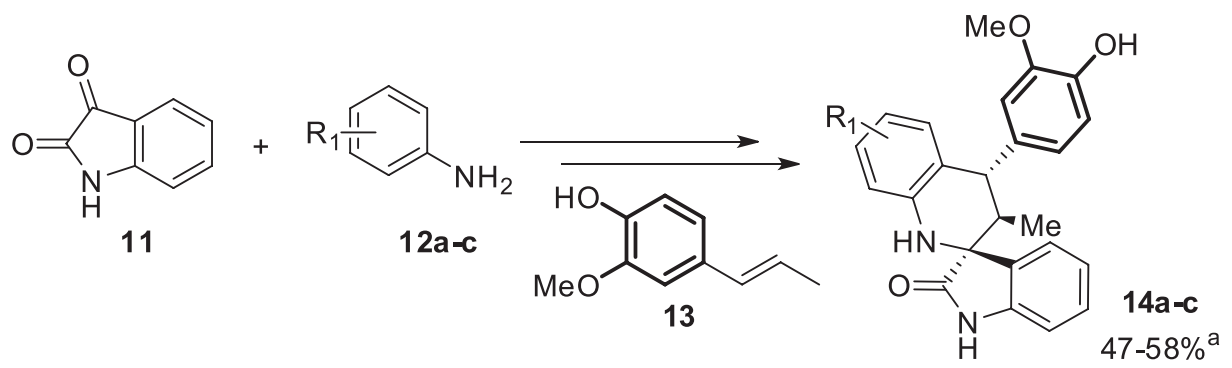<smiles>COc1cc([C@H]2c3cc(Cl)ccc3NC3(C(=O)Nc4ccccc43)[C@H]2C)ccc1O</smiles><smiles>CCc1cccc2c1N[C@@]1(C(=O)Nc3ccccc31)[C@@H](C)[C@H](c1ccc(O)c(OC)c1)c1ccccc1-2</smiles><smiles>[Y16]C1[C@H](c2ccc(O)c(OC)c2)c2cccc(C#N)c2NC12C(=O)Nc1ccccc12</smiles>

Scheme 2. Two-step synthesis of spiroisatin-dihydroquinoline hybrids 14a-14c through a Povarov reaction with trans-isoeugenol 13. Reaction conditions: first step: 11 (4 mmol), 12 (4.8 mmol), $\mathrm{AcOH}\left(5\right.$ equiv.) in $\mathrm{MeOH}(40 \mathrm{~mL})$ at $70{ }^{\circ} \mathrm{C}$ for $8 \mathrm{~h}$; the precipitated product (ketimine-isatin) was filtered and washed with petroleum ether; second step: ketimine-isatin (2 mmol), BF3. $\mathrm{OEt}_{2}(2 \mathrm{mmol})$, trans-isoeugenol $13(3 \mathrm{mmol})$ in $\mathrm{CH}_{2} \mathrm{Cl}_{2}(20 \mathrm{~mL})$ at room

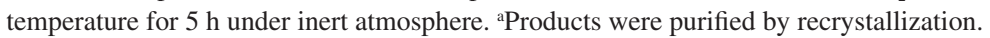




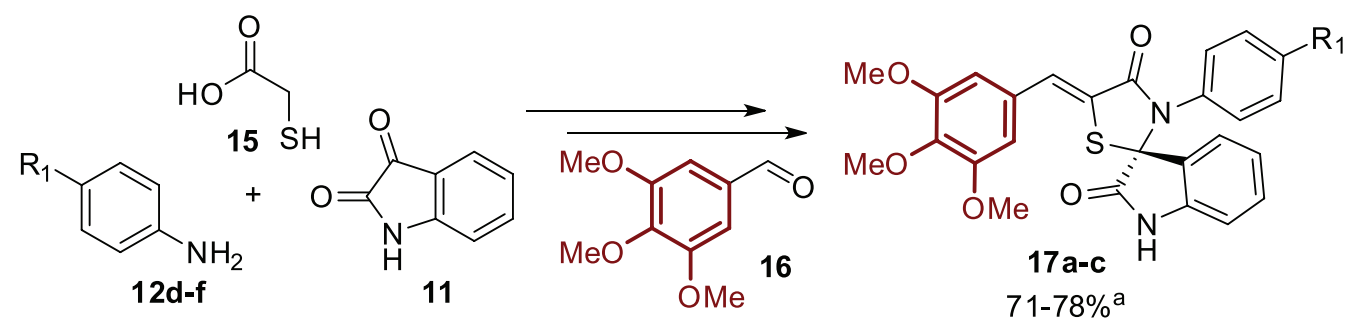<smiles>COc1ccc(N2C(=O)/C(=C/c3cc(OC)c(OC)c(OC)c3)SC23C(=O)Nc2ccccc23)cc1</smiles>

Scheme 3. Two-step synthesis of spiroisatin-thiazolidinone hybrids 17a-17c through a Knoevenagel type condensation with 3,4,5-trimethoxybenzaldehyde 16. Reaction conditions: first step: $\mathbf{1 1}(4 \mathrm{mmol}), \mathbf{1 2 d}-\mathbf{f}(4.2 \mathrm{mmol}), \mathbf{1 5}(6 \mathrm{mmol}), \mathrm{AcOH}$ (3 equiv. $)$ in toluene $(40 \mathrm{~mL})$ at $110^{\circ} \mathrm{C}$ for $8 \mathrm{~h}$; the precipitated product (spirothiazolidinone) was filtered and washed with petroleum ether; second step: spirothiazolidinone ( 2 mmol), 3,4,5-trimethoxybenzaldehyde $16(2.5 \mathrm{mmol})$ and $t$-BuOK $(3 \mathrm{mmol})$ in isopropanol (IPA) $(15 \mathrm{~mL})$ at $90{ }^{\circ} \mathrm{C}$ for $5 \mathrm{~h}$ under inert atmosphere. ${ }^{\text {aProducts }}$ were purified by recrystallization.

In total, 20 molecules, having the main pharmacophoric moieties of CA-4 1, were prepared following our described synthetic procedures. ${ }^{25,26}$ All of these small molecules were fully characterized, confirming their structure and stereochemistry by $1 \mathrm{D}\left({ }^{1} \mathrm{H}\right.$ and $\left.{ }^{13} \mathrm{C}\right) / 2 \mathrm{D}$ (correlation spectroscopy (COSY), heteronuclear multiple bond correlation (HMBC), and heteronuclear single quantum correlation (HSQC)) nuclear magnetic resonance (NMR), infrared (IR) and mass spectroscopies; ensuring their purity before they were tested on the biological assays described below.

The target compounds 10a-10c, 14a-14c, 17a-17c and 20a-20k and the reference compounds CA-4 1, colchicine 3 and doxorubicine (adriamycin), were evaluated first for their in vitro anti-proliferative activities (cytotoxicity) against three different human tumor cell lines: cervix epitheloid adenocarcinoma cell (HeLa), acute T cell leukemia (Jurkat) and promonocytic cell (U937), as well as, the non-tumor cell line Vero (African green monkey kidney, Cercopithecus aethiops). For the determination of half maximal inhibitory concentration $\left(\mathrm{IC}_{50}\right)$ values, we used the in vitro tetrazolium dye assay (3-(4,5-dimethylthiazol2-yl)-2,5-diphenyl tetrazolium bromide, MTT) according to our modified protocol. ${ }^{27}$

As shown in Table 1, compounds 17a-17c and 20a-20k did not exhibit significant anti-proliferative activities against different cancer cell lines, with an $\mathrm{IC}_{50}$ value superior to $25 \mu \mathrm{M} .{ }^{28}$ However, the substituted $\beta$-nitrostyrenes 10a-10c showed activity against HeLa and Jurkat tumor cells, being compounds $\mathbf{1 0 b}$ and $\mathbf{1 0 c}$ the most active derivatives among the tested compounds on the HeLa tumor line with
$\mathrm{IC}_{50}$ values of 16.4 and $10 \mu \mathrm{M}$, respectively. Nonetheless, the selectivity index (SI) was not significant with respect to the controls (1, $\mathbf{3}$ and doxorubicine (DOX)) (Table 1). Moreover, the $\beta$-nitrostyrene 10a resulted to be active only for the Jurkat tumor cell line with an $\mathrm{IC}_{50}$ value of $14 \mu \mathrm{M}$ and with an SI of 2.4, being the higher magnitude among the series 10a-10c, which were active and demonstrated a dose-dependent inhibition of the growth of cell lines. In addition, the spiroisatin-dihydroquinoline hybrids $\mathbf{1 4 a}$ and $\mathbf{1 4 c}$ were selective and active against one tumor cell line. Compound $\mathbf{1 4 c}$, which contains a cyanide moiety in the tetrahydroquinoline core and the 4-hydroxy3-methoxyphenyl pharmacophoric unit, exhibited a high cytotoxic activity on $\mathrm{U} 937$ cell line with an $\mathrm{IC}_{50}$ value of $13.5 \mu \mathrm{M}$.

Furthermore, the SI value of $\mathbf{1 4 c}(\mathrm{SI}=6)$ resulted to be higher than the ones shown by the positive controls CA-4 1 ( $\mathrm{SI}=4.9$ for HeLa), colchicine 3 ( $\mathrm{SI}=0.1$ for HeLa, SI $=2.1$ for Jurkat and SI $=0.3$ for U937) and doxorubicine ( $\mathrm{SI}=2.4$ for HeLa); suggesting that compound $14 \mathbf{c}$ could be considered as a possible antitumor agent (Table 1).

The in vitro antifungal activity was evaluated following the Clinical and Laboratory Standards Institute M38-A, ${ }^{29}$ protocol for filamentous fungi, with some modifications. ${ }^{30}$ The target compounds 10a-10c, 14a-14c, 17a-17c and 20a-20k, with the reference controls amphotericin B and terbinafine, were evaluated against different dermatophytes: Trichophyton mentagrophytes, Trichophyton rubrum and the environmental fungi Fusarium oxysporum (Table 2). 
<smiles>[R]c1ccc2c(c1)C(=O)C(=O)N2[R]</smiles><smiles>COc1cc(C[C@H]2[C@@H]([N+](=O)[O-])C3CCCN3[C@@]23C(=O)Nc2ccccc23)cc(OC)c1OC</smiles>

20a $77 \%$ yield $^{\mathrm{b}}$<smiles>COc1ccc(C2C([N+](=O)[O-])[C@H]3CCCN3[C@@]23C(=O)N(C)c2ccccc23)cc1OC</smiles>
$20 \mathrm{e}$ $80 \%$ yield<smiles>COc1ccc(C[C@@H]2[C@H]([N+](=O)[O-])C3CCCN3[C@@]23C(=O)Nc2ccccc23)cc1OC</smiles>

20b $78 \%$ yield $^{b}$<smiles>O=C1N(C[O+])c2ccccc2[C@@]1(Cc1ccc2c(c1)OCO2)C(C[C@H]1CCCN1)[N+](=O)[O-]</smiles>
$20 f$ $85 \%$ yield<smiles>O=C1Nc2ccccc2C12C(=O)Nc1ccccc12</smiles>

20c $75 \%$ yield $^{b}$<smiles>COc1ccc([C@H]2[C@@H]([N+](=O)[O-])[C@@H]3CCCN3[C@@]23C(=O)N(C)c2ccc(I)cc23)cc1OC</smiles>
$20 \mathrm{~g}$ $88 \%$ yield<smiles>COc1cc(C2[C@H]([N+](=O)[O-])[C@@H]3CCCN3[C@@]23C(=O)N(C)c2ccccc23)cc(OC)c1OC</smiles>

$83 \%$ yield<smiles>CCN1C(=O)[C@@]2(c3cc(Cl)ccc31)[C@H](c1ccc3c(c1)OCO3)[C@@H]1CCCN12</smiles>

$20 \mathrm{~h}$

$91 \%$ yield<smiles></smiles>

$93 \%$ yield<smiles>COc1ccc([C@H]2[C@@H]([N+](=O)[O-])[C@@H]3CCCN3[C@@]23C(=O)N(C)c2ccc([N+](=O)[O-])cc23)cc1OC</smiles>

20j $87 \%$ yield<smiles>CN1C(=O)[C@]2(C(=O)[C@H]([N+](=O)[O-])[C@@H]3CCCN32)c2cc([N+](=O)[O-])ccc21</smiles>

20k

$92 \%$ yield

Scheme 4. Synthesis of spiroisatin-nitropyrrolizidine hybrids 20a-20k through a regioselective 1,3-dipolar cycloaddition under aqueous media. Reaction

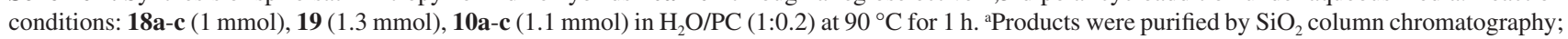
${ }^{\mathrm{b}}$ combined yield of the isolated mixture of regioisomers.

We found that among the all tested compounds in all the strains evaluated, only the group of $\beta$-nitrostyrenes 10a-10c resulted to be active (minimal inhibitory concentration $(\mathrm{MIC}) \leq 100 \mu \mathrm{M})$. These molecules were classified according to their MIC values as follows: 10c $>10 b>10 a$ (Table 2).

$\beta$-Nitrostyrene 10c showed the most important antifungal activity against $T$. mentagrophytes, $T$. rubrum and $F$. oxysporum at concentrations $25.7,40.6$ and $32.4 \mu \mathrm{M}$, respectively. The activity of $\beta$-nitrostyrenes 10a-10c against F. oxysporum outstands over the other strains because this fungus has been associated with systemic diseases that show high mortality rates and strong resistance to several antifungal agents. ${ }^{31}$

We have found in previous studies that some CA-4 1 hybrids containing the (Z)-2-(3,4,5-trimethoxystyryl) furan moiety have showed interesting antifungal activity against $T$. mentagrophytes and T. rubrum, giving MIC values of $15.7 \pm 6.8$ and $15.8 \pm 6.5 \mu \mathrm{g} \mathrm{mL}^{-1}$, respectively. ${ }^{32}$ Furthermore, the antifungal activity of $\mathbf{1 0} \mathbf{c}$ was previously determined against $C$. albicans ATCC 90028 giving an MIC value of $32.0 \mu \mathrm{g} \mathrm{mL}^{-1} .33$

The results of this study confirm that the 3,4,5-trimethoxy phenyl moiety should be the fragment, which improves the antifungal activity, especially against $T$. mentagrophytes, allowing to conclude that this pharmacophoric subunit of CA-4 1 is also relevant for the development of novel antidermatophytes agents.

Finally, the in vitro antiviral activity of all the synthesized compounds 10a-10c, 14a-14c, 17a-17c and 20a-20k, with the reference control acyclovir and CA-4, were evaluated against human herpesvirus 1 (HHV-1 
Table 1. In vitro anti-proliferative activity (cytotoxicity) of all the synthesized compounds measured by the MTT test in four human tumor cell lines

\begin{tabular}{|c|c|c|c|c|c|c|c|}
\hline \multirow{3}{*}{ Compound } & \multicolumn{7}{|c|}{ Cell line ${ }^{a}$} \\
\hline & \multicolumn{2}{|c|}{$\mathrm{HeLa}$} & \multicolumn{2}{|c|}{ Jurkat } & \multicolumn{2}{|c|}{ U937 } & \multirow{2}{*}{$\begin{array}{c}\text { Vero } \\
\mathrm{IC}_{50} \pm \mathrm{SD}^{\mathrm{b}} / \mu \mathrm{M}\end{array}$} \\
\hline & $\mathrm{IC}_{50} \pm \mathrm{SD}^{\mathrm{b}} / \mu \mathrm{M}$ & $\mathrm{SI}^{\mathrm{c}}$ & $\mathrm{IC}_{50} \pm \mathrm{SD}^{\mathrm{b}} / \mu \mathrm{M}$ & $\mathrm{SI}^{\mathrm{c}}$ & $\mathrm{IC}_{50} \pm \mathrm{SD}^{\mathrm{b}} / \mu \mathrm{M}$ & $\mathrm{SI}^{\mathrm{c}}$ & \\
\hline 1 & $19.91 \pm 3.3$ & 4.9 & $\mathrm{NT}^{\mathrm{f}}$ & $\mathrm{NT}^{\mathrm{f}}$ & $\mathrm{NT}^{\mathrm{f}}$ & $\mathrm{NT}^{\mathrm{f}}$ & $97.0 \pm 0.7$ \\
\hline 3 & $0.01 \pm 0.001$ & 0.1 & $0.0006 \pm 0.00001$ & 2.1 & $0.005 \pm 0.001$ & 0.3 & $0.001 \pm 0.0001$ \\
\hline $10 \mathrm{a}$ & $>25$ & $\mathrm{NA}^{\mathrm{d}}$ & $14.0 \pm 1.9$ & 2.4 & $26.4 \pm 0.2$ & 1.3 & $33.1 \pm 2.6$ \\
\hline 10b & $10.0 \pm 1.06$ & 1.6 & $12.5 \pm 2.2$ & 1.3 & $29.1 \pm 0.7$ & 0.5 & $15.7 \pm 0.4$ \\
\hline $10 \mathrm{c}$ & $16.4 \pm 0.46$ & 0.8 & $>25$ & $\mathrm{NA}^{\mathrm{d}}$ & $28.2 \pm 0.6$ & 0.5 & $13.0 \pm 0.4$ \\
\hline $14 a$ & $>25$ & $\mathrm{NA}^{\mathrm{d}}$ & $>25$ & $\mathrm{NA}^{\mathrm{d}}$ & $14.7 \pm 5.3$ & 4.8 & $70.9 \pm 1.1$ \\
\hline $14 b$ & $>25$ & $\mathrm{NA}^{\mathrm{d}}$ & $>25$ & $\mathrm{NA}^{\mathrm{d}}$ & $>25$ & $\mathrm{NA}^{\mathrm{d}}$ & $>25$ \\
\hline $14 \mathrm{c}$ & $>25$ & $\mathrm{NA}^{\mathrm{d}}$ & $>25$ & $\mathrm{NA}^{\mathrm{d}}$ & $13.5 \pm 0.2$ & 6.0 & $80.8 \pm 2.98$ \\
\hline $17 \mathbf{a}$ & $>25$ & $\mathrm{NA}^{\mathrm{d}}$ & $>25$ & $\mathrm{NA}^{\mathrm{d}}$ & $>25$ & $\mathrm{NA}^{\mathrm{d}}$ & $>25$ \\
\hline $17 \mathrm{~b}$ & $>25$ & $\mathrm{NA}^{\mathrm{d}}$ & $>25$ & $\mathrm{NA}^{\mathrm{d}}$ & $>25$ & $\mathrm{NA}^{\mathrm{d}}$ & $>25$ \\
\hline $17 \mathrm{c}$ & $>25$ & $\mathrm{NA}^{\mathrm{d}}$ & $>25$ & $\mathrm{NA}^{\mathrm{d}}$ & $>25$ & $\mathrm{NA}^{\mathrm{d}}$ & $>25$ \\
\hline $20 \mathrm{a}$ & $>25$ & $\mathrm{NA}^{\mathrm{d}}$ & $>25$ & $\mathrm{NA}^{\mathrm{d}}$ & $>25$ & $\mathrm{NA}^{\mathrm{d}}$ & $>25$ \\
\hline $20 \mathrm{~b}$ & $>25$ & $\mathrm{NA}^{\mathrm{d}}$ & $>25$ & $\mathrm{NA}^{\mathrm{d}}$ & $>25$ & $\mathrm{NA}^{\mathrm{d}}$ & $>25$ \\
\hline $20 \mathrm{c}$ & $>25$ & $\mathrm{NA}^{\mathrm{d}}$ & $>25$ & $\mathrm{NA}^{\mathrm{d}}$ & $>25$ & $\mathrm{NA}^{\mathrm{d}}$ & $>25$ \\
\hline 20d & $>25$ & $\mathrm{NA}^{\mathrm{d}}$ & $>25$ & $\mathrm{NA}^{\mathrm{d}}$ & $>25$ & $\mathrm{NA}^{\mathrm{d}}$ & $>25$ \\
\hline $20 \mathrm{e}$ & $>25$ & $\mathrm{NA}^{\mathrm{d}}$ & $>25$ & $\mathrm{NA}^{\mathrm{d}}$ & $>25$ & $\mathrm{NA}^{\mathrm{d}}$ & $>25$ \\
\hline $20 f$ & $>25$ & $\mathrm{NA}^{\mathrm{d}}$ & $>25$ & $\mathrm{NA}^{\mathrm{d}}$ & $>25$ & $\mathrm{NA}^{\mathrm{d}}$ & $>25$ \\
\hline $20 \mathrm{~g}$ & $>25$ & $\mathrm{NA}^{\mathrm{d}}$ & $>25$ & $\mathrm{NA}^{\mathrm{d}}$ & $>25$ & $\mathrm{NA}^{\mathrm{d}}$ & $>25$ \\
\hline $20 \mathrm{~h}$ & $>25$ & $\mathrm{NA}^{\mathrm{d}}$ & $>25$ & $\mathrm{NA}^{\mathrm{d}}$ & $>25$ & $\mathrm{NA}^{\mathrm{d}}$ & $>25$ \\
\hline $20 \mathrm{i}$ & $>25$ & $\mathrm{NA}^{\mathrm{d}}$ & $>25$ & $\mathrm{NA}^{\mathrm{d}}$ & $>25$ & $\mathrm{NA}^{\mathrm{d}}$ & $>25$ \\
\hline $20 j$ & $>25$ & $\mathrm{NA}^{\mathrm{d}}$ & $>25$ & $\mathrm{NA}^{\mathrm{d}}$ & $>25$ & $\mathrm{NA}^{\mathrm{d}}$ & $>25$ \\
\hline $20 \mathrm{k}$ & $>25$ & $\mathrm{NA}^{\mathrm{d}}$ & $>25$ & $\mathrm{NA}^{\mathrm{d}}$ & $>25$ & $\mathrm{NA}^{\mathrm{d}}$ & $>25$ \\
\hline $\mathrm{DOX}^{\mathrm{e}}$ & $0.8 \pm 0.1$ & 2.4 & $0.1 \pm 0.007$ & 19.0 & $0.1 \pm 0.01$ & 19.0 & $1.9 \pm 0.08$ \\
\hline
\end{tabular}

${ }^{a}$ HeLa: human cervix epithelial adenocarcinoma cells ATCC CRL-1958; Jurkat: human acute T cell leukemia ATCC TIB-152; U937: human promonocytic cell line ATCC CRL-1593.2; Vero: Cercopithecus aethiops African green monkey kidney cells ATCC CCL-81; ${ }^{b} \mathrm{C}_{50}$ : concentration of the compound causing $50 \%$ cell growth inhibition after $48 \mathrm{~h}$ of compounds exposure, as determined by the MTT assay; 'SI: selectivity index defined as VERO IC $_{50}$ over either HeLa, Jurkat or U937 $\mathrm{IC}_{50}$; ${ }^{\mathrm{d} N A}$ : not active; ${ }^{\mathrm{p}}$ positive control; ${ }^{\mathrm{r}} \mathrm{NT}$ : not tested. SD: standard deviation.

CDC Atlanta acyclovir-sensitive strain) and human herpesvirus 2 (HHV-2 VR-734-G acyclovir-sensitive strain). The determination of the reduction factor $\left(\mathrm{R}_{\mathrm{f}}\right)$, which corresponds to the value obtained by dividing the viral titer in the absence of compound over the viral titer obtained in the presence of compound was employed as an end point of this antiviral bioassay (Table 3). ${ }^{34}$

In a previous study carried out in our laboratory, ${ }^{32}$ we reported the antiviral activity of combretastatin A-4 hybrid of HHV-2 at concentrations below 25.0 and $3.1 \mu \mathrm{g} \mathrm{mL}^{-1}$. This background is important and establishes a guide for continue exploring antiviral activity. ${ }^{32}$

In order to determine the relevant or moderate antiviral activity of tested compounds, the reduction of $R_{f}$ was established as a criterion to classify their potency according to the standard parameters. ${ }^{30}$ Nevertheless, only the spiroisatin-dihydroquinoline hybrids $\mathbf{1 4 b - 1 4 c}$ exhibited moderate anti-herpetic activity, classifying them according to those parameters as follows: $14 c>14 b>14 a$. Interestingly, the potency of compounds $14 a, 14 b$ and $14 c$, with an $\mathrm{R}_{\mathrm{f}}$ of $1 \times 10^{2}$, against HHV-2 at concentrations $25,15.2$ and $15.1 \mu \mathrm{M}$, respectively, can be correlated with the in vitro anti-proliferative activity of these compounds discussed above against U937.

It should be noted that the spiroisantin hybrids have a broad-spectrum biological activities, which involves antimicrobial. ${ }^{35}$ In the particular case of the spiro[indoline3,2'-quinolin]-2-one hybrid $\mathbf{1 4 c}$, it is clear that the presence of the nitrile $(\mathrm{CN})$ moiety is important to improve the cytotoxic and the anti-herpetic activity, while the ethyl group and chlorine atoms at the same core decreases both activities. 
Table 2. In vitro antifungal activity of all the synthesized compounds

\begin{tabular}{|c|c|c|c|}
\hline \multirow{2}{*}{ Compound } & \multicolumn{3}{|c|}{ Antifungal activity (MIC) $)^{\mathrm{a}, \mathrm{b}} / \mu \mathrm{M}$} \\
\hline & T. mentagrophytes & T. rubrum & F. oxysporum \\
\hline $10 \mathrm{a}$ & 82.9 & $>100$ & $>100$ \\
\hline $10 \mathrm{~b}$ & 59.8 & 59.8 & 59.8 \\
\hline $10 \mathrm{c}$ & 25.7 & 40.6 & 32.4 \\
\hline $14 a$ & $>100$ & $>100$ & $>100$ \\
\hline $14 b$ & $>100$ & $>100$ & $>100$ \\
\hline $14 \mathrm{c}$ & $>100$ & $>100$ & $>100$ \\
\hline $17 \mathbf{a}$ & $>100$ & $>100$ & $>100$ \\
\hline $17 \mathrm{~b}$ & $>100$ & $>100$ & $>100$ \\
\hline $17 \mathrm{c}$ & $>100$ & $>100$ & $>100$ \\
\hline 20a & $>100$ & $>100$ & $>100$ \\
\hline $20 \mathrm{~b}$ & $>100$ & $>100$ & $>100$ \\
\hline $20 \mathrm{c}$ & $>100$ & $>100$ & $>100$ \\
\hline 20d & $>100$ & $>100$ & $>100$ \\
\hline $20 \mathrm{e}$ & $>100$ & $>100$ & $>100$ \\
\hline $20 f$ & $>100$ & $>100$ & $>100$ \\
\hline $20 \mathrm{~g}$ & $>100$ & $>100$ & $>100$ \\
\hline $20 \mathrm{~h}$ & $>100$ & $>100$ & $>100$ \\
\hline $20 \mathrm{i}$ & $>100$ & $>100$ & $>100$ \\
\hline $20 \mathrm{j}$ & $>100$ & $>100$ & $>100$ \\
\hline $20 \mathrm{k}$ & $>100$ & $>100$ & $>100$ \\
\hline Terbinafine & 0.0268 & 0.0268 & $\mathrm{NT}^{\mathrm{c}}$ \\
\hline
\end{tabular}

${ }^{\mathrm{a}}$ Geometric means of minimal inhibitory concentration (MIC) of tested compounds; 'be other positive control, amphotericin B, showed an antifungal activity of $1.1 \mu \mathrm{M}$ against A. fumigatus and A. flavus; 'NT: not tested.

Other compound that exhibited good antiviral activity belongs to the family of spiroisatin-nitropyrrolizidine hybrids 20a-20k. With the 3,4-methylenedioxy phenyl moiety, the derivative 20c resulted active against HHV-2, reducing to one hundred times the challenged viral load but at concentration of $31.8 \mu \mathrm{M}$. While the group of $\beta$-nitrostyrenes 10a-10c showed no activity against human herpesviruses, the spiroisatin-thiazolidinone hybrids, $\mathbf{1 7 c}$, revealed effectiveness against HHV-1 at concentration $99.1 \mu \mathrm{M}$.

For anti-dengue activity, we highlight the effectiveness of the molecules 14a, 14b and 17c. In this case, 14a and 14b molecules revealed an activity efficiency at a concentration of 30.2 and $29.7 \mu \mathrm{M}$, respectively (Figure 2). In addition, the $17 \mathbf{c}$ molecule showed activity at various concentrations $(198.2,99.1$ and $49.5 \mu \mathrm{M})$. Finally, for the antiviral assay with dengue virus, we employed ribavirin as control for each experiment.

The treatment with the $\mathbf{1 4 a}, \mathbf{1 4 b}$ and $\mathbf{1 7} \mathrm{c}$ molecules in dengue virus infected cells also caused visible
Table 3. In vitro antiviral activity of all the synthesized compounds

\begin{tabular}{|c|c|c|c|c|}
\hline \multirow{3}{*}{ Compound } & \multicolumn{4}{|c|}{ Vero cell line ${ }^{a}$} \\
\hline & \multicolumn{2}{|c|}{ HHV-1 } & \multicolumn{2}{|c|}{ HHV-2 } \\
\hline & $\mathrm{R}_{\mathrm{f}}^{\mathrm{b}}$ & $\begin{array}{c}\text { Antiviral } \\
\text { activity / } \mu \mathrm{M}\end{array}$ & $\mathrm{R}_{\mathrm{f}}^{\mathrm{b}}$ & $\begin{array}{c}\text { Antiviral } \\
\text { activity / } \mu \mathrm{M}\end{array}$ \\
\hline $10 \mathrm{a}$ & $\mathrm{NA}^{\mathrm{c}}$ & $\mathrm{NA}^{\mathrm{c}}$ & $\mathrm{NA}^{\mathrm{c}}$ & $\mathrm{NA}^{\mathrm{c}}$ \\
\hline 10b & $\mathrm{NA}^{\mathrm{c}}$ & $\mathrm{NA}^{\mathrm{c}}$ & $\mathrm{NA}^{\mathrm{c}}$ & $\mathrm{NA}^{\mathrm{c}}$ \\
\hline $10 \mathrm{c}$ & $\mathrm{NA}^{\mathrm{c}}$ & $N^{c}$ & $\mathrm{NA}^{\mathrm{c}}$ & $\mathrm{NA}^{\mathrm{c}}$ \\
\hline $14 a$ & $\mathrm{NA}^{\mathrm{c}}$ & $\mathrm{NA}^{\mathrm{c}}$ & $10^{2}$ & 25 \\
\hline $14 \mathrm{~b}$ & $\mathrm{NA}^{\mathrm{c}}$ & $\mathrm{NA}^{\mathrm{c}}$ & $10^{2}$ & 15.1 \\
\hline $14 c$ & $10^{2}$ & 60.8 & $10^{2}$ & 15.2 \\
\hline $17 \mathbf{a}$ & $\mathrm{NA}^{\mathrm{c}}$ & $\mathrm{NA}^{\mathrm{c}}$ & $\mathrm{NA}^{\mathrm{c}}$ & $\mathrm{NA}^{\mathrm{c}}$ \\
\hline $17 b$ & $\mathrm{NA}^{\mathrm{c}}$ & $\mathrm{NA}^{\mathrm{c}}$ & $\mathrm{NA}^{\mathrm{c}}$ & $\mathrm{NA}^{\mathrm{c}}$ \\
\hline $17 \mathrm{c}$ & $10^{2}$ & 99.1 & $\mathrm{NA}^{\mathrm{c}}$ & $\mathrm{NA}^{\mathrm{c}}$ \\
\hline 20a & $\mathrm{NA}^{\mathrm{c}}$ & $\mathrm{NA}^{\mathrm{c}}$ & $\mathrm{NA}^{\mathrm{c}}$ & $\mathrm{NA}^{\mathrm{c}}$ \\
\hline $20 \mathrm{~b}$ & $\mathrm{NA}^{\mathrm{c}}$ & $\mathrm{NA}^{\mathrm{c}}$ & $\mathrm{NA}^{\mathrm{c}}$ & $\mathrm{NA}^{\mathrm{c}}$ \\
\hline $20 \mathrm{c}$ & $\mathrm{NA}^{\mathrm{c}}$ & $\mathrm{NA}^{\mathrm{c}}$ & $10^{2}$ & 31.8 \\
\hline 20d & $\mathrm{NA}^{\mathrm{c}}$ & $\mathrm{NA}^{\mathrm{c}}$ & $\mathrm{NA}^{\mathrm{c}}$ & $\mathrm{NA}^{\mathrm{c}}$ \\
\hline $20 \mathrm{e}$ & $\mathrm{NA}^{\mathrm{c}}$ & $\mathrm{NA}^{\mathrm{c}}$ & $\mathrm{NA}^{\mathrm{c}}$ & $\mathrm{NA}^{\mathrm{c}}$ \\
\hline $20 f$ & $\mathrm{NA}^{\mathrm{c}}$ & $\mathrm{NA}^{\mathrm{c}}$ & $\mathrm{NA}^{\mathrm{c}}$ & $\mathrm{NA}^{\mathrm{c}}$ \\
\hline $20 \mathrm{~g}$ & $\mathrm{NA}^{\mathrm{c}}$ & $\mathrm{NA}^{\mathrm{c}}$ & $\mathrm{NA}^{\mathrm{c}}$ & $\mathrm{NA}^{\mathrm{c}}$ \\
\hline $20 \mathrm{~h}$ & $\mathrm{NA}^{\mathrm{c}}$ & $\mathrm{NA}^{\mathrm{c}}$ & $\mathrm{NA}^{\mathrm{c}}$ & $\mathrm{NA}^{\mathrm{c}}$ \\
\hline $20 \mathrm{i}$ & $\mathrm{NA}^{\mathrm{c}}$ & $\mathrm{NA}^{\mathrm{c}}$ & $\mathrm{NA}^{\mathrm{c}}$ & $\mathrm{NA}^{\mathrm{c}}$ \\
\hline $20 j$ & $\mathrm{NA}^{\mathrm{c}}$ & $\mathrm{NA}^{\mathrm{c}}$ & $\mathrm{NA}^{\mathrm{c}}$ & $\mathrm{NA}^{\mathrm{c}}$ \\
\hline $20 \mathrm{k}$ & $\mathrm{NA}^{\mathrm{c}}$ & $\mathrm{NA}^{\mathrm{c}}$ & $\mathrm{NA}^{\mathrm{c}}$ & $\mathrm{NA}^{\mathrm{c}}$ \\
\hline 1 & $10^{0.5}$ & 149.5 & $10^{2}$ & 74.8 \\
\hline Acyclovir & $10^{4}$ & 6.7 & $10^{4}$ & 6.7 \\
\hline
\end{tabular}

${ }^{a}$ Vero Cercopithecus aethiops African green monkey kidney cell line ATCC CCL-81; breduction factor: ratio of the virus titer in the absence over virus titer in the presence of the tested compound; 'NA: not active. HHV-1: human herpesvirus 1 CDC Atlanta strain; HHV-2: human herpesvirus 2 VR-734-G strain.

morphological alterations under the microscope (data not shown), which are usually related to cytoskeleton remodeling. Several studies ${ }^{36,37}$ have shown roles for tubulin during DNA and RNA viral infections, cancers and other pathological processes.

This would explain the broad spectrum of biological activity of the combretastatin hybrids included in this study, regarding CA-4 inhibitory activity in microtubule polymerization.

A key criterion for designing and developing new drugs is considering broad activity against medically important pathogens.

These results are important because the design and development of new drugs must take their activity spectrum into consideration, and a strong preference must be given to drug candidates that are active against the largest number 
(a)

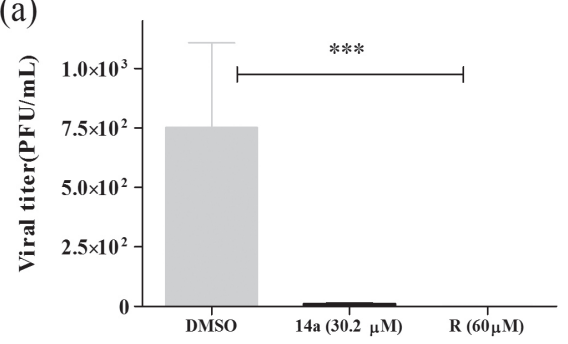

(b)

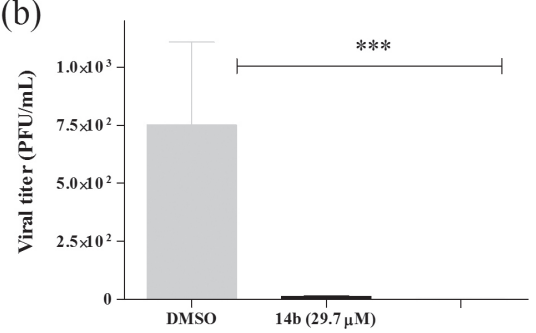

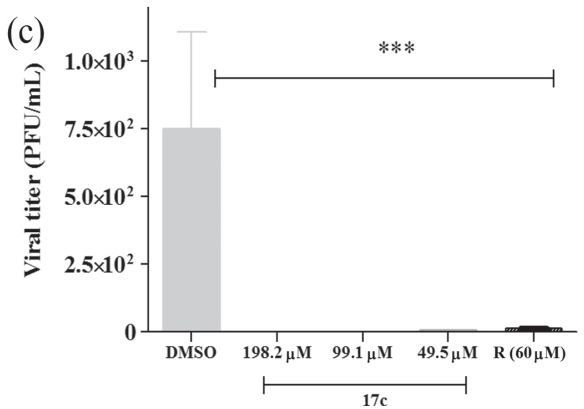

Figure 2. Molecules 14a, 14b and 17c were effective in DENV-2 infection. BHK-21 cells were incubated in the presence or absence of 14a (a); 14b (b) and 17c (c) molecules for six days and plaque forming units (PFU) were count, using as control ribavirin (R). Mean and SD: standard deviation compared to dimethyl sulfoxide (DMSO) and ribavirin control from three experiments are shown. $p$-Values were determined by two-tailed unpaired $t$-test $(* * *$ : $p<0.001 ; * *: 0.001<p<0.01 ; *: 0.01<p<0.05)$.

of co-circulating viruses and other pathogens that use the cell to perpetuate themselves and to cause pathology.

We carried out in silico assays using molecular docking to establish the mechanism of action of the tested molecules, that could explain their broad biological activities. The results showed molecules group 10a-c binding to $\alpha$-tubulin through hidrofobic interactions in the residues: Ala12, Tyr 224, Gln 11, Gly 144, Gly 10, Thr 145, Gly 146, Glu 183, Gly 142, Gly 143 and Ser 140 (Figures 3a-3c). The binding affinities (in kcal mol${ }^{-1}$ ) obtained were: 10a $(-7.2)$, 10b (-6.7) and 10c (-7.1) (Figures 3a-3c).

In addition, the molecules 14a-14b were docked, and unlike the 10a-10c compounds, these structures formed hydrogen bonds $(\mathrm{Hb})$ with the $\alpha$-tubulin. In the case of $\mathbf{1 4 a}$, the following $\mathrm{Hb}$ on the amino acids were shown: Leu 242, (a)

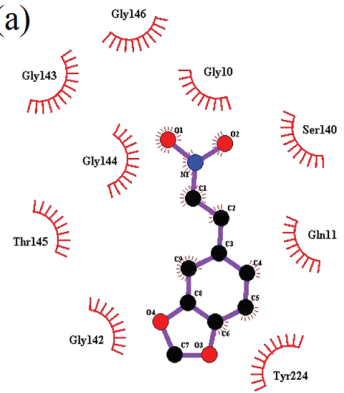

$10 \mathbf{a}\left(-7.2 \mathrm{kcal} \mathrm{mol}^{-1}\right)$ (b)

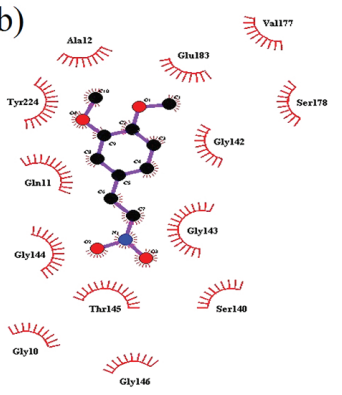

$10 b\left(-6.7 \mathrm{kcal} \mathrm{mol}^{-1}\right)$
Arg48 and Lys 96 (Figure 3d) and the 14b showed $\mathrm{Hb}$ on Arg42 (Figure 3e). The $\mathrm{Hb}$ interactions have high stability which is relevant to explain the molecule activity. On the contrary, the compounds exhibited hydrophobic bindings that are less stable than $\mathrm{Hb}$. Otherwise, the $\mathbf{1 4 c}$ molecule interacts on the colchicine binding-site, nonetheless, the interactions are hydrophobic (Figure 3f).

The compound $17 \mathrm{c}$ binds to subunit $\alpha / \beta$-tubulin with an affinity $-8.8 \mathrm{kcal} \mathrm{mol}^{-1}$ (Figure $3 \mathrm{~g}$ ). Interestingly, we observed an $\mathrm{Hb}$ on Arg 2 and Asn 50 residues. According with the crystallographic structure reported by Ravelli et al. ${ }^{36}$ and Nogales et al. ${ }^{38}$ the site of interaction between microtubules and compounds is different to the colchicine site. The results showed interaction in a region near to the nucleotide exchange area of tubulin, this is (e)

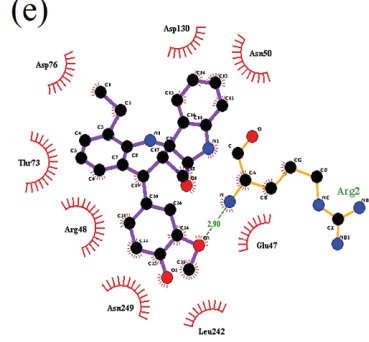

14b $\left(-8.3 \mathrm{kcal} \mathrm{mol}^{-1}\right)$

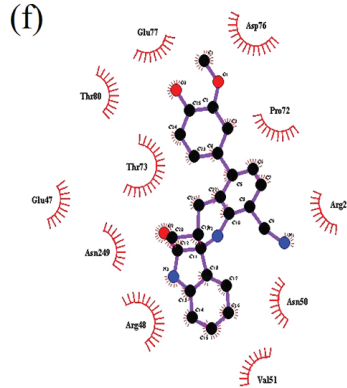

$14 \mathrm{c}\left(-9.6 \mathrm{kcal} \mathrm{mol}^{-1}\right)$ (c)

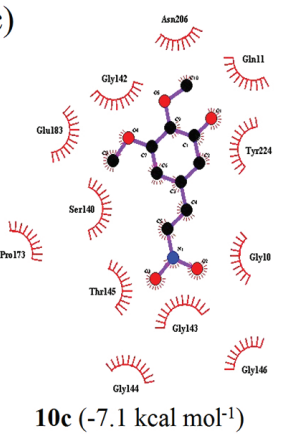

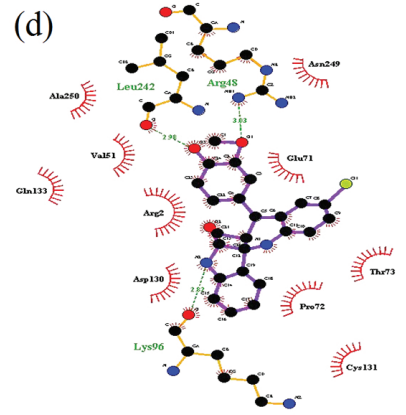

$14 \mathbf{a}\left(-9.8 \mathrm{kcal} \mathrm{mol}^{-1}\right)$

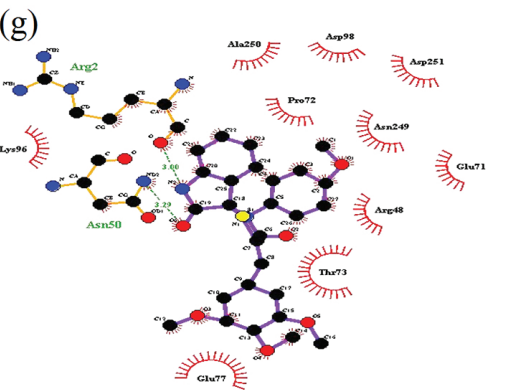

$17 \mathrm{c}\left(-8.8 \mathrm{kcal} \mathrm{mol}^{-1}\right)$

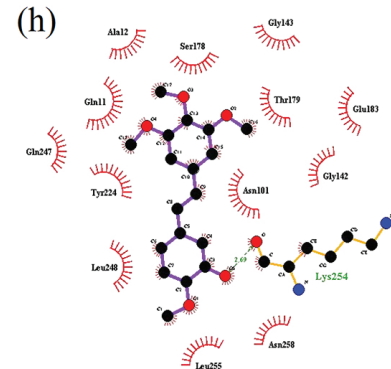

CA-4 (-7.1 kcal mol-1)

Figure 3. Molecular docking of molecules 10a-10c (a-c); 14a-14c (d-f); 17c ( $\mathrm{g}$ ) and combretastatin A-4 (h). Each docking shows in parentheses the binding affinities expressed in $\mathrm{kcal} \mathrm{mol}^{-1}$. Hydrogen bounds are represented in a dotted line (green) and hydrophobic interactions are shown in red color. 
relevant because the exchange of guanine nucleotide is required for the microtubule assembly.

Further, the control CA-4 was docked and as expected, it showed interaction in the colchicine binding site (Figure 3h). Finally, as perspective, we suggest biological validation of in silico results, i.e., to evaluate alterations in the tubulin pattern in a treatment context as well as determining if the possible changes are related to the biological activities reported here.

\section{Conclusions}

In this study, a series of styrene 10a-10c and spiroisatin hybrids, containing the dihydroquinoline 14a-14c, thiazolidinone 17a-17c and nitropyrrolizidine 20a-20k pharmacophoric subunits, were synthesized based on the structure of combretastatin A-4 1. The cytotoxicity, antifungal and antiviral activities of these libraries were evaluated for the first time.

Biological results revealed that among the diverse molecules tested with methoxy and/or hydroxy groups substituting the benzene rings, some compounds resulted active. $\beta$-Nitrostyrenes 10a-10c exhibited notable data in two biological activities (cytotoxicity and antifungal); in particular, 3,4-dimethoxy- $\beta$-nitrostyrene $\mathbf{1 0 b}$ displayed the highest cytotoxic activity among the tested series having the 3,4-methylenedioxy fragment.

Although none of the spiroisatin-thiazolidinone hybrids 17a-17c exhibited representative activities (cytotoxic, antifungal or antiviral), our findings are relevant to encourage search of novel antitumoral, antifungal and antiherpetic agents. Additionally, the in silico studies demonstrated that these molecules could interact with tubulin in different areas compared to the colchicine binding site, suggesting a different mechanism of action.

\section{Experimental}

\section{Chemistry}

General procedure for the synthesis of $\beta$-nitrostyrenes 10a-10c

Into a $10 \mathrm{~mL}$ round bottom flask equipped with a condenser, a gas bubbler and a stir bar, it was added the corresponding benzaldehyde $\mathbf{8 a - 8 c}$ ( $5 \mathrm{mmol}, 1$ equiv.) and nitromethane 9 (20 mmol, 4 equiv.). The reaction mixture was stirred at $90{ }^{\circ} \mathrm{C}$ and $0.1 \mathrm{~g}$ of catalyst $\left(\mathrm{ETAM} / \mathrm{SiO}_{2}\right)$ was added in one portion. The system was stirred at this temperature for six hours until the thin layer chromatography (TLC) monitoring confirmed the end of the reaction, then the reaction mixture was cooled at room temperature and the catalyst was filtered and the filtrate was extracted three times with $\mathrm{CH}_{2} \mathrm{Cl}_{2}(3 \times 20 \mathrm{~mL})$. The organic layer was separated, dried with $\mathrm{Na}_{2} \mathrm{SO}_{4}$, and concentrated under reduced pressure to yield the pure product $10 \mathrm{a}-10 \mathrm{c}$. Characterization data for 10a-10c is included in the Supplementary Information section associated to this article.

General method for the synthesis of spiroisatin-thiazolidinone hybrids $17 a-17 c$

A mixture of isatin $\mathbf{1 1}$ (4 mmol), the corresponding aniline 12d-12f (4.2 $\mathrm{mmol})$ and acetic acid (3 equiv.) in anhydrous toluene $(40 \mathrm{~mL})$ was refluxed for $3 \mathrm{~h}$ and thioglycolic acid 15 (6.04 mmol) was then added after $15 \mathrm{~min}$. The reaction mixture was refluxed with a Dean-Stark apparatus for $8 \mathrm{~h}$. After cooling, the reaction mixture was concentrated and added to a saturated $\mathrm{NaHCO}_{3}$ solution. The obtained product, the spirothiazolidinone, was filtered and recrystallized. Without further purification, the respective intermediate ( $2 \mathrm{mmol}), 3,4,5$-trimethoxybenzaldehyde $16(2.5 \mathrm{mmol})$ and potassium tert-butoxide $(3 \mathrm{mmol})$ in isopropanol (IPA, $15 \mathrm{~mL}$ ) was heated at $90{ }^{\circ} \mathrm{C}$ for $5 \mathrm{~h}$ under nitrogen atmosphere. TLC monitoring confirmed the end of the reaction, then the reaction mixture was cooled at room temperature and acetic acid $(1 \mathrm{~mL})$ was added. The precipitate was filtered and recrystallized to yield the desired products. Characterization data for 17a-17c is included in the Supplementary Information section associated to this article.

General procedure for the synthesis of the spirooxindoles 1'-nitro pyrrolizidines 20a-20k

Into a $15 \mathrm{~mL}$ round bottom flask equipped with a condenser, a gas bubbler and a stir bar, it was added the corresponding isatin 18a-18c (2.50 mmol, 1 equiv.), the respective $\beta$-nitrostyrene 10a-10c (1.1 equiv.), $1 \mathrm{~mL}$ of distilled water and $0.2 \mathrm{~mL}$ of propylene carbonate. The reaction mixture was stirred at $90{ }^{\circ} \mathrm{C}$ for 15 min prior to addition of the appropriate L-proline 19 (1.3 equiv.) and then the mixture was stirred at this temperature for one hour controlling the bubbling of $\mathrm{CO}_{2}$. TLC monitoring confirmed the end of the reaction, then the reaction mixture was cooled at room temperature and quenched with saturated sodium bicarbonate solution $(10 \mathrm{~mL}, 1 \mathrm{M})$ and was extracted three times with $\mathrm{CH}_{2} \mathrm{Cl}_{2}(3 \times 20 \mathrm{~mL})$. The organic layer was separated, dried with $\mathrm{Na}_{2} \mathrm{SO}_{4}$, and concentrated to afford the crude product, which was purified by silica gel flash chromatography to yield the corresponding spirooxindole 1'-nitro pyrrolizidines 20a-20k. Characterization data for 20a-20k is included in the Supplementary Information section associated to this article. 


\section{Biology}

In vitro anti-proliferative activity assay

The in vitro anti-proliferative activities of CA-4 1 and all of the target compounds were determined by the MTT (Sigma, New Jersey, USA) assay as described previously. ${ }^{27}$ Briefly, Vero (african green monkey kidney, ATCC CCL-81) and HeLa (human cervix epithelial carcinoma, ATCC CRL-1958) cell lines were seeded into 96-well plates at $2.0 \times 10^{3}$ cells per well and incubated for $24 \mathrm{~h}$ at $37^{\circ} \mathrm{C}$. After the incubation time, each diluted compound was added to the appropriate wells and the plates were incubated for further $48 \mathrm{~h}$ at $37{ }^{\circ} \mathrm{C}$ in a humidified incubator with $5 \% \mathrm{CO}_{2}$. Jurkat (acute $\mathrm{T}$ cell leukemia human, ATCC TIB-152) and U937 (promonocytic, ATCC CRL-1593.2) cell lines were centrifuged to remove medium and were again suspended in culture medium and plated at $3 \times 10^{3}$ cells per well in a 96-well roundbottomed plate and diluted compounds were added to plates and incubated for $48 \mathrm{~h}$ at $37^{\circ} \mathrm{C}$. Subsequently, the culture medium was removed and the MTT solution $(24 \mu \mathrm{L}$, $2 \mathrm{mg} \mathrm{mL}^{-1}$ ) was added to each well. The minimal dilution of compound that induced 50\% growth inhibition of the cells was expressed as inhibitory concentration $50 \%\left(\mathrm{IC}_{50}\right)$. The $\mathrm{IC}_{50}$ values for each compound were obtained by linear regression analysis of the dose-response curves generated from the absorbance data with the statistical package $\mathrm{R}^{39} \mathrm{IC}_{50}$ values were expressed as the mean \pm standard deviation (mean $\pm \mathrm{SD}$ ) of two independent experiments done in quadruplicate. Also, the selectivity index (SI) was calculated.

\section{In vitro antifungal activity assay}

The dilutions of the compounds were dispensed into 96-well flat-bottom microdilution plates in duplicate at final concentrations between 100-20 $\mu \mathrm{M}$. Amphotericine B was used as control with Aspergillus fumigatus and Aspergillus flavus at a range of 17.3-0.034 $\mu \mathrm{M}$, and terbinafine with dermatophytes were used as positive controls at a range of 0.031-13.72 $\mu \mathrm{M}$. The inoculum size for microdilution plates were $0.2-2.5 \times 10^{5}$ colony forming units (CFU) $\mathrm{mL}^{-1}$. For the CLSI M38-A method, ${ }^{29}$ the MICs were determined after $48 \mathrm{~h}$ of incubation at $35^{\circ} \mathrm{C}$ to Aspergillus spp. and at $28^{\circ} \mathrm{C}$ to Fusarium oxysporum. The activity against the dermatophytes was determined after 6 days of incubation at $28{ }^{\circ} \mathrm{C}$.

\section{In vitro antiviral activity assay}

The anti-herpetic activity of molecules was evaluated on Vero cells against ten cell culture infectious dose fifty percent $\left(10 \mathrm{TCID}_{50}\right)$ of HHV-1 and HHV-2, using the end-point titration technique (EPTT). ${ }^{27}$ The activity was evaluated by determining the reduction factor $\left(\mathrm{R}_{\mathrm{f}}\right)$ that corresponds to the ratio of viral titer treated with respect to titer viral untreated. For this assay, two independent experiments were carried out by quadruplicate and acyclovir was included as positive control. According to the established parameters, ${ }^{27}$ the relevant or moderate antiviral activity of a purified natural product is one whose $R_{f}$ of viral titer is $\geq 1 \times 10^{3}$ or $1 \times 10^{2}$, respectively. ${ }^{28}$

To determine the anti-DENV activity, baby hamster kidney (BHK-21) cell monolayers grown in 24-well plates $5.5 \times 10^{4}$ cells per well were infected with multiplicity of infection $(\mathrm{MOI})=1$. Treatments were performed by adding compounds either simultaneously with virus (preinfection treatment) or after viral infection (post-infection treatment). For pre-infection treatment, a virus/compound mixture was added to cell monolayers and was incubated for $2 \mathrm{~h}$ at $37{ }^{\circ} \mathrm{C}\left(5 \% \mathrm{CO}_{2}\right)$. After incubation, a washing step was performed with phosphate buffered saline (PBS, $\mathrm{pH}$ 7.0) then it was added carboxymethyl cellulose (CMC) $1.5 \%$. In post-infection treatment, virus was added on cell monolayer and incubated for $2 \mathrm{~h}$ at $37^{\circ} \mathrm{C}\left(5 \% \mathrm{CO}_{2}\right)$. After, washing was performed with PBS (pH 7.0), compounds previously prepared in CMC $1.5 \%$ were added and plates were incubated for six days. Cells were then fixed and stained with a solution of $3.5 \%$ formaldehyde with $0.2 \%$ crystal violet and viral plaques were counted. Dextran sulfate was employed as positive control in pre-infection assays. Ribavirin (RIBA) was used as positive control in post-infection stages of DENV-2. The fifty effective concentration $\left(\mathrm{EC}_{50}\right)$ was defined as the concentration that reduces the $50 \%$ of plaque forming units. $\mathrm{EC}_{50}$ for each compound were obtained by linear regression analysis of the dose-response curves generated using the statistical program GraphPad Prism 5.0. ${ }^{40}$

\section{In silico (docking) studies}

Molecular docking studies were perfomed using AutoDock Vina ${ }^{41}$ to determine whether the synthesized compounds have comparable binding mode to that of CA-4 on the $\alpha, \beta$-tubulin subunit that corresponds to the colchicine binding site. This area is formed by the following amino acids: $\alpha$-tubulin: Thr179, Val 181, Ser 178; $\beta$-tubulin: Cys 241, Ala 250, Lys 254, Leu 255, Asn 258, Met 259, Ala 316, Ala 317, Lys 352, Thr 353, Ile 378.

In this study, the most active compounds (10a-10c, 14a-14c and 17c) were docked into colchicine binding site of the crystal structure of tubulin (PDB code: 3E22). For the visualization of interactions, it was employed $\mathrm{LigPlot}^{+}$ software. ${ }^{42}$ 


\section{Supplementary Information}

Supplementary information (experimental details, characterization data, including copies of ${ }^{1} \mathrm{H}$ NMR, ${ }^{13} \mathrm{C}$ NMR, DEPT-135, COSY, ${ }^{13} \mathrm{C}$ HMBC, HSQC and HSQC charts, of all synthesized compounds) is available free of charge at http://jbcs.sbq.org.br as PDF file.

\section{Acknowledgments}

We acknowledge the financial support from Colciencias (Patrimonio Autónomo del Fondo Nacional de Financiamiento para la Ciencia, la Tecnología y la Innovación, Francisco José de Caldas-Colombia), grant 7442016 (contract 648-2017 project 1115744555595); CODI (Comité para el Desarrollo de la Investigación-Universidad de Antioquia), grant 2014-1041; and Estrategia de Sostenibilidad (CODI) 2016-2017 de la Universidad de Antioquia and Banco de la República (agreement 201510). We thank Dr Miguel A. González Cardenete, associate researcher at Consejo Superior de Investigaciones Científicas (CSIC), Spain, for his generous donation of CA-4 $\mathbf{1}$.

\section{References}

1. Chaudhary, A.; Pandeya, S. N.; Kumar, P.; Sharma, P. P.; Gupta, S.; Soni, N.; Verma, K. K.; Bhardwaj, G.; Mini-Rev. Med. Chem. 2007, 7, 1186.

2. Greene, L. M.; Meegan, M. J.; Zisterer, D. M.; J. Pharmacol. Exp. Ther. 2015, 355, 212.

3. Dumontet, C.; Jordan, M. A.; Nat. Rev. Drug Discovery 2010, 9, 790 .

4. Etienne-Manneville, S.; Curr. Opin. Cell Biol. 2010, 22, 104.

5. Sanghai, N.; Jain, V.; Preet, R.; Kandekar, S.; Das, S.; Trivedi, N.; Mohapatra, P.; Priyadarshani, G.; Kashyap, M.; Das, D.; Satapathy, S. R.; Siddharth, S.; Guchhait, S. K.; Kundu, C. N.; Bharatam, P. V.; Med. Chem. Commun. 2014, 5, 766.

6. Ohsumi, K.; Nakagawa, R.; Fukuda, Y.; Hatanaka, T.; Morinaga, Y.; Nihei, Y.; Ohishi, K.; Suga, Y.; Akiyama, Y.; Tsuji, T.; J. Med. Chem. 1998, 41, 3022; Chen, J.; Liu, T.; Dong, X.; Hu, Y.; Mini-Rev. Med. Chem. 2009, 9, 1174.

7. Jin, Y.; Qi, P.; Wang, Z.; Shen, Q.; Wang, J.; Zhang, W.; Song, H.; Molecules 2011, 16, 6684.

8. Lippert III, J. W.; Bioorg. Med. Chem. 2007, 15, 605.

9. Lu, Y.; Chen, J.; Xiao, M.; Li, W.; Miller, D. D.; Pharm. Res. 2012, 29, 2943.

10. Sackett, D. L.; Pharmacol. Ther. 1993, 59, 163.

11. Jaganathan, S. K.; Mazumdar, A.; Mondhe, D.; Mandal, M.; Cell Biol. Int. 2011, 35, 607.

12. Antonchick, A. P.; Gerding-Reimers, C.; Catarinella, M.; Schürmann, M.; Preut, H.; Ziegler, S.; Rauh, D.; Waldmann,
H.; Nat. Chem. 2010, 2, 735; Wang, S.; Zhao, Y.; Zhang, G.; Lv, Y.; Zhang, N.; Gong, P.; Eur. J. Med. Chem. 2011, 46, 3509.

13. Kanthou, C.; Tozer, G. M.; Blood 2002, 99, 2060; Hsu, L. C.; Durrant, D. E.; Huang, C. C.; Chi, N. W.; Baruchello, R.; Rondanin, R.; Rullo, C.; Marchetti, P.; Grisolia, G.; Simoni, D.; Lee, R. M.; Invest. New Drugs 2012, 30, 1379.

14. Gahlmann, A.; Moerner, W. E.; Nat. Rev. Microbiol. 2014, 12, 9.

15. Ferreira, D.; Cortez, M.; Atayde, V. D.; Yoshida, N.; Infect. Immun. 2006, 74, 5522; Jewett, T. J.; Sibley, L. D.; Mol. Cell 2003, 11, 885 .

16. Takeshita, N.; Manck, R.; Grün, N.; de Vega, S. H.; Fischer, R.; Curr. Opin. Microbiol. 2014, 20, 34; Berepiki, A.; Lichius, A.; Read, N. D.; Nat. Rev. Microbiol. 2011, 9, 876.

17. Delorme-Axford, E.; Coyne, C. B.; Viruses 2011, 3, 2462; Sun, X.; Whittaker, G. R.; Cell. Microbiol. 2007, 9, 1672.

18. Coccetti, P.; Montano, G.; Lombardo, A.; Tripodi, F.; Orsini, F.; Pagliarin, R.; Bioorg. Med. Chem. Lett. 2010, 20, 2780.

19. Taylor, M. P.; Koyuncu, O. O.; Enquist, L. W.; Nat. Rev. Microbiol. 2011, 9, 427.

20. Mainou, B. A.; Zamora, P. F.; Ashbrook, A. W.; Dorset, D. C.; Kim, K. S.; Dermodya, T. S.; mBio 2013, 4, e00405; Dietzel, E.; Kolesnikova, L.; Maisner, A.; Virol. J. 2013, 10, 249.

21. Radtke, K.; Kieneke, D.; Wolfstein, A.; Michael, K.; Steffen, W.; Scholz, T.; Karger, A.; Sodeik, B.; PLoS Pathog. 2010, DOI 10.1371/journal.ppat.1000991.

22. Naghavi, M. H.; Walsh, D.; J. Virol. 2017, DOI 10.1128/ JVI.00538-17.

23. Castro, M. A.; Gamito, A. M.; Tangarife-Castaño, V.; RoaLinares, V.; del Corral, J. M. M.; Mesa-Arango, A. C.; BetancurGalvis, L.; Francesch, A. M.; San Feliciano, A. S.; RSCAdv. 2015, 5, 1244; Martínez Bonilla, C. A.; Puerto Galvis, C. E.; Vargas Méndez, L. Y.; Kouznetsov, V. V.; RSC Adv. 2016, 6, 37478.

24. Mora, M.; Jiménez-Sanchidrián, C.; Urbano, F. J.; Ruiz, J. R.; Catal. Lett. 2010, 134, 131.

25. Kouznetsov, V. V.; Bello Forero, J.; Amado Torres, D. F.; Tetrahedron Lett. 2008, 49, 5855.

26. Puerto Galvis, C. E.; Kouznetsov, V. V.; Org. Biomol. Chem. 2013, 11, 7372.

27. Kouznetsov, V. V.; Merchán Arenas, D. R.; Tangarife Castaño, V.; Correa Royero, J.; Betancur Galvis, L.; Med. Chem. Res. 2016, 25, 429.

28. Cos, P.; Vlietinck, A. J.; Berghe, D. V.; Maes, L.; J. Ethnopharmacol. 2006, 106, 290.

29. Clinical and Laboratory Standards Institute (CLSI); Document M38-A: Reference Method for Broth Dilution Antifungal Susceptibility Testing of Filamentous Fungi; Approved Standard; CLSI: Wayne, USA, 2002.

30. Vlietinck, A. J.; Van Hoof, L.; Totté, J.; Lasure, A.; Berghe, D. V.; Rwangabo, P. C.; Mvukiyumwami, J.; J. Ethnopharmacol. 1995, 46, 31 . 
31. Triest, D.; Piérard, D.; De Cremer, K.; Hendrickx, M.; Commun. Integr. Biol. 2016, 9, e1162934.

32. González, M. A.; Pérez-Guaita, D.; Agudelo-Goméz, L. S.; Tangarife-Castaño, V.; Zapata, B.; Betancur-Galvis, L.; Nat. Prod. Commun. 2012, 7, 1051.

33. Pettit, R. K.; Pettit, G. R.; Hamel, E.; Hogan, F.; Moser, B. R.; Wolf, S.; Pon, S.; Chapuis, J. C.; Schmidt, J. M.; Bioorg. Med. Chem. 2009, 17, 6606.

34. Food and Drug Administration Center for Drug Evaluation and Research; Guidance for Industry, Antiviral Product Development - Conducting and Submitting Virology Studies to the Agency; U. S. Department of Health and Human Services, Rockville, USA, 2006.

35. Mohammadi, A. A.; Askari, S.; Rohi, H.; Soorki, A. A.; Synth. Commun. 2014, 44, 457.
36. Ravelli, R. B.; Gigant, B.; Curmi, P. A.; Jourdain, I.; Lachkar, S.; Sobel, A.; Knossow, M.; Nature 2004, 428, 198.

37. Naghavi, M. H.; Walsh, D.; J. Virol. 2017, 91, e00538-17.

38. Nogales, E.; Whittaker, M.; Milligan, R. A.; Downing, K. H.; Cell 1999, 96, 79.

39. Software R, version 4.0; Development Core Team, Vienna, Austria, 2008.

40. GraphPad Prism 5.0; GraphPad Software Inc., San Diego, CA, USA, 2009.

41. Trott, O.; Olson, A. J.; J. Comput. Chem. 2009, 31, DOI: $10.1002 /$ jcc. 21334.

42. Laskowski, R. A.; Swindells, M. B.; J. Chem. Inf. Model. 2011, $51,2778$.

Submitted: July 5, 2019

Published online: November 26, 2019 